5. Digitales Wörterbuch der deutschen Sprache [Електронне видання]. URL: https://www.dwds.de/ (дата звернення: 02.02.2021).

6. English Oxford Living Dictionaries [Електронне видання]. URL: https://en.oxforddictionaries.com/ (дата звернення: 24.01.2021).

DOI https://doi.org/10.30525/978-9934-26-073-5-2-11

\title{
ОСОБЛИВОСТІ ЗАСТОСУВАННЯ СТРУКТУРНОГО МЕТОДУ В МОВОЗНАВЧИХ ДОСЛІДЖЕННЯХ
}

\author{
Волянюк I. О. \\ кандидат філологічних наук, \\ доиент кафедри української мови і літератури та методик їх навчання \\ Кременечької обласної гуманітарно-педагогічної академії \\ імені Тараса Шевченка \\ м. Кременещь, Тернопільська область, Україна
}

Загальновідомо, що мова $є$ системою. Вона складається з ієрархічно вибудуваних мовних рівнів, які поділяють на дві групи: основні та проміжні. Під рівнями розуміємо «деякі „ділянки» мови, підсистеми мовної системи, кожну 3 яких характеризують сукупність відносно однорідних одиниць і набір правил, які регулюють їх використання i групування в різні класи і підкласи» [2, с. 214]. До основних рівнів належать ті, що мають основну одиницю. 3-поміж них: фонологічний, морфологічний, лексичний і синтаксичний. У мові, як і в будь-якій системі, одиниці одного рівня взаємодіють із одиницями інших рівнів. Саме завдяки такій взаємодії функціонують проміжні рівні. До них відносять морфонологічний, словотвірний і фразеологічний.

У сучасних методологічних працях науково описано низку методів, за допомогою яких здійснюються мовознавчі дослідження різного характеру. Проте лінгвістичних розвідок, присвячених вивченню застосування структурного методу для дослідження мовних одиниць різних рівнів обмаль. 3 огляду на це тему нашої роботи вважаємо актуальною.

Тож метою публікації є обгрунтування важливості структурного методу в лінгвістичних дослідженнях, а також аналіз його прийомів під час вивчення одиниць мови.

Що ж називається структурним методом у лінгвістиці? За визначенням М. Кочергана, - це «метод синхронного аналізу мовних явищ лише на основі зв'язків і відношень між мовними елементами» 46 
[2, с. 372]. О. Селіванова зазначає: «Структурний метод як головний спосіб аналізу мови у структуралістській парадигмі представлений різноманітними методиками синхронного аналізу мовних явищ як варіантів складників цілісної системи мови - інваріантів, які перебувають у жорстко детермінованій внутрішній ієрархії відношень. Він служить пізнанню внутрішньої організації мови як системи із притаманними їй інваріантними елементами, що в мовленні співвідносяться 3 регламентованими конкретними реалізаціями; відношеннями між елементами, які впорядковують елементи в ієрархію мовних рівнів». [3, с. 55]

Складовими структурного методу є дистрибутивний аналіз, методика безпосередніх складників, трансформаційний та компонентний аналіз. Кожен із них може бути використаний при дослідженні мовних одиниць різних рівнів.

Так, методикою дистрибутивного аналізу (тобто, «дослідження мови на основі оточення (розподілу) окремих одиниць у тексті» [1]) часто послуговуються науковці, студенти, магістранти для дослідження лексичних одиниць різних груп. Наприклад, при вивченні полісемантів, омонімів тощо. Саме шляхом уведення слова в контекст (оточення) з'ясовується та конкретизується його семантика. Ця методика також може бути застосована під час дослідження морфології, морфеміки та словотвору. Наприклад, для іменників 3 абстрактним значенням характерними є суфікси: -ість, -от(а), -анн(я), -енн(я). Проте вибір морфеми при творенні иього класу слів зумовлюється логічними взаємозв'язками: добрий - доброта, хоробрий - хоробрість, навчати навчання і под.

Близькою до дистрибутивного аналізу $є$ методика безпосередніх складників, яка «являє собою сукупність процедур представлення синтаксичної структури словосполучення ... або речення у вигляді розкладення цілого на його складники, компоненти яких також можуть бути розкладені на компоненти до рівня кінцевих складників» [3, c. 57-58]. Дещо ширший аспект цієї методики охарактеризовано М. Кочерганом: це «прийом подання словотвірної структури слова i синтаксичної структури словосполучення та речення у вигляді ієрархії складових елементів» [2, с. 377]. Виходячи із наведених визначень, методика безпосередніх складників доповнює дистрибутивний аналіз i може також використовуватися при дослідженні морфемної будови слів, словотвору та синтаксису. Саме прийом безпосередніх складників, на нашу думку, доцільно застосовувати при визначенні напрямку похідності, побудові словотвірних гнізд і ланцюжків (оскільки похідні у словотвірному ланцюжку перебувають у відношеннях послідовної 
мотиваціі), визначенні типу відношень між твірним і похідними словами. Проілюструємо це прикладами творення словотвірних ланцюжків 3 вихідним словом ліс: ліс $\rightarrow$ лісний $\rightarrow$ лісник $\rightarrow$ лісничиха; ліс $\rightarrow$ лісок $\rightarrow$ лісочок; ліс $\rightarrow$ лісовий $\rightarrow$ лісовик $\rightarrow$ лісовичка. У вивченні синтаксису ця методика допомагає визначати ядро речення (предикативний центр), встановлювати логіко-смислові відношення між членами речення, а також досліджувати структурні особливості синтаксичних конструкцій.

За М. Кочерганом, трансформаційний аналіз - це «експериментальний прийом визначення синтаксичних і семантичних подібностей i відмінностей між мовними об'єктами через подібності й відмінності в наборах їх трансформацій» [2, с. 381]. Цей прийом може бути корисним при вивченні морфології та синтаксису, а також словотвору. Так, наприклад, граматична категорія дієслівного стану виражає відношення дії до суб'єкта і об'єкта. Суб'єктно-об'єктні відношення можуть виявляються саме в реченні. Дієслово $\epsilon$ основною ланкою в реалізації граматичних відношень між суб'єктом і об'єктом дії. Так, у реченні Актор виконує роль суб'єктом дії виступає слово актор; дія, виконувана суб'єктом як активним діячем, спрямована на об'єкт (роль), що в реченні виступає прямим додатком. У наведеній конструкції логічні відношення суб'єкта і об'єкта збігаються з граматичними; дієслово виражає значення активної дії - тобто, дієслово активного стану. Проте ці ж логічні відношення можна передати в іншому граматичному оформленні, наприклад: Роль виконується актором. У такому варіанті речення дієслово виконується виступає зі значенням пасивної дії. Логічний суб'єкт при такій трансформації виражається залежною формою іменника - орудним відмінком суб'єкта, а логічний об'єкт виступає у формі називного відмінка.

Метою компонентного аналізу «є встановлення структури значення слова як певним чином організованої сукупності елементарних змістовних одиниць - сем (семантичних множників)» [3, с. 55]. Тож цей прийом $є$ найефективнішим при дослідженні семантики повнозначних слів, у перекладознавстві та в укладанні словників.

Отже, всі компоненти структурного методу - важливі й необхідні у лінгвістичних дослідженнях. Зокрема, прийомами дистрибутивного аналізу та безпосередніх складників доцільно послуговуватися при вивченні фонем (одиниць фонологічного рівня), лексем (одиниць лексичного рівня), морфем і частин мови (одиниць морфологічного рівня), синтаксем (одиниць синтаксичного рівня); методика трансформаційного аналізу корисна при дослідженні синтаксем i частин мови; компонентний аналіз - основа дослідження сем - смислових (лексичних) одиниць. 


\title{
Література:
}

1. Дистрибутивний аналіз. URL: https://uk.wikipedia.org/wiki

2. Кочерган М. П. Загальне мовознавство: підручник. К., 2006. 464 с.

3. Селіванова О. О. Сучасна лінгвістика: напрями та проблеми: підручник. Полтава, 2008. 712 с.

DOI https://doi.org/10.30525/978-9934-26-073-5-2-12

\section{ЖАРГОННІ ФРАЗЕОЛОГІЗМИ ЯК ОСОБЛИВА СКЛАДОВА МІСЬКОГО МОВЛЕННЯ}

\author{
Гарлицька Т. C. \\ кандидат філологічних наук, \\ доцент кафедри англійської мови з методикою викладання \\ Криворізького державного педагогічного університету \\ м. Кривий Ріг, Дніпропетровська область, Украӥна
}

Вивчення мови сучасного міста $\epsilon$ одним із найактуальніших питань соціолінгвістики, основним завданням якої $є$ «чітка скерованість на соціальну природу мови, іiї комунікативну функцію, відношення мови й суспільства, поведінки соціально заангажованого індивіда» [1, с. 71]. Тому під час дослідження міського мовлення важливо враховувати усі суспільно-політичні, економічні, соціальні, культурні зрушення, які відбуваються сьогодні в окремій країні та у світі в цілому. Одними з таких змін $\epsilon$ розкутість сучасного суспільства, демократизація ЗМІ та художньої літератури, прагнення містян підвищити свій соціальний статус, різні види соціальних потрясінь, які стали причиною активного творення та функціонування нелітературних одиниць не лише в усному, але й у писемному мовленні.

До нелітературних / субстандартних елементів, які функціонують у мовленні міста, ми зараховуємо лексичні та фразеологічні одиниці проміжних / периферійних типів (просторіччя, койне, суржик, піджин, креол, інтердіалект) та різні види соціальних діалектів (сленг, професійний та корпоративний жаргон, арго). Питанням збагачення та функціонування некодифікованих фразеологічних елементів присвячено низку праць зарубіжних та вітчизняних мовознавців (Е. Партридж, Г. Менкен， В.Флейшер，А.Бахі， Р. Менон， М. Маковський， О. Сербенська, О. Стишов, О. Тараненко, Н. Третяк). Задля виявлення типових рис жаргонних фразеологізмів, які функціонують у мовленні будь-якого 